\title{
The understanding of the concepts of first language, second language and foreign language outside of Latvia
}

\author{
Inga Laizane Mg. philol. \\ Riga Stradins University, Liepaja University, Latvia \\ inga.laizane7@inbox.lv
}

\begin{abstract}
Both in Latvia and in the world the concept of first language, second language and foreign language exist, but often there is a different understanding of them, especially with regard to the terms of the second language and foreign language, therefore it is useful to find out how the concepts of the first language, the second language and the foreign language are understood and used in the world. These terms are used in language learning, in educational theory and in sociology. Since depending on different situations language may have different language status, the aim of the article is to ascertain how the concepts of first language, second language and foreign language are understood outside of Latvia. The main method used in this research is the study of scientific literature, summarizing the most significant works of foreign authors, which explain the terms of the first language, the second language and the foreign language. The study found that the term second language is used extensively outside of Latvia, describing the second language acquired chronologically, the majority language that the minorities know as well as any language other than the mother tongue. The results obtained in the study make it possible to compare the comprehension and use of the concepts of the first language, the second language and the foreign language outside Latvia and in Latvia. The author of the article has publications on the use of terms of the first language, the second language and the foreign language in Latvia and in exile conditions. Thus, the results obtained allow us to conclude that foreign researchers sometimes choose the term second language as a convenient and overarching term to designate both foreign language and second language in the sense understood by the Latvian researchers, even though also abroad these are two distinct concepts, however, in Latvia the distinction between them is more specific.
\end{abstract}

Keywords: first language, second language, foreign language, adult education.

\section{Introduction}

After birth a person learns a language, which is commonly referred to as the mother tongue. At school, the person learns some other language, which is usually regarded as foreign language, but during the lifetime he/she moves to a country where he/she no longer speaks his/her mother tongue or even the foreign language he/she has learned at school, therefore the person learns another language. The given example shows that in different life situations the language may have different language status, that is, the language can be understood as the first language, second language or foreign language. Moreover, the understanding of these terms varies from country to country. It should also be pointed out that these terms can be used in various branches of science - in linguistics, pedagogy, as well as in sociolinguistics and psychology.

The author of this article has previously studied how the terms first language, second language and foreign language are understood and used in Latvia. That particular study found that in Latvia the term first language is characterized by features such as language learned in early childhood, the best-managed language and genetically inherited language. Which of these features to put forward as the predominant one when defining the first language depends on each individual, but it does not always allow you to teach your mother tongue according to your native language programs and standards. It is important to emphasize that the terms second language and foreign language in Latvia are rather distinct, and this distinction has existed in pedagogy for a long period of time as two different directions of lingua-didactics - Latvian language as a second language (LAT2) and Latvian as a foreign language (LATS) - have developed.

A study on the status of the Latvian language in exile has also been published, which reflects the fact that according to the language classification L1/L2/L3 used in the world and in Latvia, the exiles and exiled authors perceive the Latvian language as L1, the concept of which includes terms mother tongue, father tongue, home language, first language, native language, family language, kitchen language, heritage language, national heritage language, ancestral language and minority language for referring to the Latvian language in exile, as well as L3, which is most frequently perceived as a foreign language in Latvia and in the world. 
The aim of the article is to determine how the concepts of first language, second language and foreign language are understood outside of Latvia, what the content of these concepts is and what may cause discussions as regards to the definition and understanding of these concepts.

\section{Methodology}

This article is part of a broader study on the development of the Latvian language as a foreign language both in Latvia and abroad. One of the study's theoretical parts deals also with the terminological issues.

This article is based on scientific literature studies. The most important research by foreign authors, which explain the concepts of the first language, second language, and foreign language. In order to make it easier to understand the concepts of a second language and a foreign language that are very similar and sometimes not distinction in foreign scientific literature, several features were distinguished, which are characteristic for both concepts.

\section{Results and Discussion}

The following article explains the understanding of the concept of first language, second language and foreign language as well as the difficulties arising from the interpretation of these notions.

\section{Understanding the concept of first language}

In foreign scientific literature, the first language (L1) is understood as the first language the child learns. The terms mother tongue or native language are also used. Often foreign literature also uses the term primary language (Loewen, Reinders, 2011, XI; Gass, Selinker, 2008, 7) when referring to the first language. In a situation where a person speaks only one language, there is no discussion of what his first language is. However, the situation is more complex in a multilingual environment, in which a child learns two languages at the same time. Some individuals can learn a single language since birth, but then acquire better knowledge of another language. However, the context of that statement makes it clear which is the person's native language. Therefore, the next language to be acquired is considered to be the second language (Loewen, Reinders, 2011, XI). This allows us to conclude that Latvian authors have a wider understanding of the term native language, which includes the fact that it can also be the best-acquired language.

G. Cook, just like the Latvian researcher I. Druviete, believes that the child may also have several native languages. G. Cook uses the term home language (Cook, 2003, 128), which is deemed to refer to the language that is used in the family. In many migrant environments, the status of the first language in the migrant's family changes during certain periods. The parents can preserve their native language as a means of communication at home, but their children will increasingly use the vast language of the neighbourhood to communicate with each other, as well as with their parents and sometimes even grandparents. In such an environment, the first language loses its special status and becomes the second or third language for the younger generation (De Bot, Lowie, Verspoor, 2005, 6).

In countries such as England and France, many children are socializing in a linguistically diverse environment, and it seems clear which their first language is. But most people in the world are multilingual, and it's not clear to many people what makes up their first, second, or third language. A child can learn one or two other languages at school, and later in life even learn and use another language to such an extent that the first foreign language is not used for a long time and disappear. It is unclear how the terms second language and third language would be significant in such cases. Some linguists rank terms of the language, depending on their skill level, other linguists rank them according to the time of learning, but none of these differences apply to children who have two or more languages since birth. In this case, the first, the second or the third language can only be defined depending on the environment (De Bot, Lowie, Verspoor, 2005, 6). Comparing how the Latvian scientists use the terms of the first and the second language, it can be concluded that the term first language, which is also considered to be a native language, includes the fact that an individual can have two or more languages since birth, and all of them will be the native languages of an individual. In the Latvian terminology, it is not the practice to make a distinction between the terms first native language and the second native language, as is often done in foreign literature. Moreover, the definition of the native language in the dictionary of linguo-didactic terms developed by the Latvian authors also clearly shows the environment of the mother tongue use i.e. family or school. 


\section{Understanding the concept of second language}

The second language has several features characterizing this term. First of all, any language that is different from the native language.

Mostly in the world, the term second language is understood as any language, thus including a foreign language that is acquired after the native language (Mitchell, Myles, 2013, 5-6; Gass, Selinker, 2008, 7; Loewen, Reinders, 2011, XI; Smith, 2014, 7; Ellis, 1997, 3; White, 2003, XII). Foreign researchers also emphasize that the term second language is not used to refer to a second language acquired chronologically. For some people, it may be the third or even fourth language acquired during his lifetime, thus it is a general term that stands for the acquisition of any language that is different from the native language.

Secondly, the language environment.

Often, foreign scientists emphasize the importance of the environment in which language is learned. This means that the second language is a language which is acquired in a country where this language is an official language (De Bot, Lowie, Verspoor, 2005, 7; Littlewood, 1998, 3; Cook, 2003, 131; Kramsch, 2008, 4; Crystal, 2003; Johnson, Johnson, 1999, 133-134). G. Cook defines the second language as the language of majority or the official language of the respective country, which is not the native language of the language learner (Cook, 2003, 131). D. Crystal uses the term official language as it is used as a means of communication in such areas as public administration, litigation, the media and the education system. He also emphasizes that this language is usually described as a second language, since it is considered to be complementary to the native or first language of an individual (Crystal, 2003). Latvian researchers highlight this feature as the main one when using the term second language.

Thirdly, the way in which the language is acquired. The foreign researchers point out that learning a second language can take both guided (intentional) and natural language learning (Ellis, 1997, 3; Gass, Selinker, 2008; 7; Kramsch, 2008, 5).

\section{Understanding the concept of a foreign language}

Although the term second language has several meanings and it is often used extensively, foreign language literature also uses the term foreign language. Abbreviations L3, L4 are sometimes used in the theoretical literature when referring to languages acquired successively after the second language (L2), so they could be considered foreign languages. Therefore, the features specific to the concept of a foreign language will be further explained.

Firstly, the language environment.

Many researchers agree that the term foreign language is generally refers to the acquisition of the nonnative language in the language of the native speaker, for example, French speakers are learning English language in France (Gass, Selinker, 2008, 7; Ellis, 1997, 11; De Bot, Lowie, Verspoor, 2005, 7; Littlewood, 1998, 3; Cook, 2003, 128; Crystal, 2003). Therefore, a foreign language has no social function in the environment in which it is acquired, and there are usually no or very few persons who speak in the language that is being acquired in this environment.

Secondly, the purpose of language acquisition.

Sometimes foreign researchers emphasize that the term foreign language can be used when an individual stay in a country temporarily, usually associated with education or work, and guidelines for learning foreign language and textbooks are published in the country of origin. These guidelines reflect the goals and values of the education system of the country concerned (Kramsch, 2008, 5; Johnson, Johnson, 1999, 134). TThis means that the official language used in the country, which is used by the people living there, can be a foreign language, but important factor is the length of stay of these people, i.e. it is a temporary stay. Such language definition has been facilitated by the jobseekers moving to more economically developed country, with a purpose of short-stay, as well as due to the students' desire or the need to study abroad. This view is also emphasized by D. Larsen-Freeman, a researcher in teaching and learning theory of the English language and M.H. Long (Larsen-Freeman, Long, 2014), professor at the University of Maryland.

Thirdly, the way, in which the language is acquired. 
Sometimes the researchers emphasise that the term foreign language refers to a language which the person is motivated to learn by incentive rather than to learn naturally, thus it is taught but the person fails to learn it (Knapp, Seidlhofer, Widdowson, 2011, 3). Of course, in this context language learning for educational purposes can also addressed as a topic, for example, classical languages like Latin language taught in certain fields, for example, to medical students.

\section{Understanding the concept of third language}

The term foreign language is frequently referred to in the theoretical literature, but sometimes the term third language, which is designated by the abbreviation L3, occur occasionally as well. It might seem that these terms are synonymous, but it is not entirely true. The second language encyclopaedia suggests that a person can learn a third language only when he/she has a prior knowledge of two or more languages, usually including at least one non-native language (Robinson, 2013, 644). This means that, for example, members of minorities residing in Latvia, first of all, have knowledge of their mother tongue, secondly, knowledge of the official language, and, thirdly, for example, knowledge of English language, which in this case could be considered as a third language. This would be an applicable explanation only if Section 5 of the State Language Law is taken into account, within the meaning of which the Latvian language for members of minorities should be regarded as a foreign language.

I. Bliska explains that in the scientific literature the term third language (L3) applies to both the language acquired as a second foreign language and, more generally, to the language acquired after the second foreign language. Thus, the concept of the third language confirms the presence of three languages in the learning process or in the communication situation (Bliska, 2015, 89-90). This explanation could very well be applied to foreigners who come to Latvia and learn Latvian as a foreign language, as they usually have a knowledge of their native language and knowledge of at least one foreign language, most often knowledge of English, but sometimes also knowledge of other languages, for example, French. In this case, they will learn Latvian as a regular foreign language, which could also be defined as a third language, although in terms of the number of languages studied, it could be even the fourth or fifth language that they learn.

The term third language is generally referred to the third language that the language learner acquires in the chronological order, but in a more general sense, this term is used to refer to any language that is acquired by the multilingual language learner at the particular time. So, it certainly does not have to be the third language in a row. The third language learners are different from those who are acquiring a nonnative language (L2) for the first time because they have previous language learning experience and more diverse knowledge of the language (Robinson, 2013, 644-645).

In general, it should be concluded that the use of the term third language or foreign language could be important for the learner himself, so that he can define, for example, the status of the Latvian language when learning it. From a linguo-didactic point of view, the language learner will learn it anyway as a foreign language, regardless of which consecutive foreign language it will be for him.

The combination of concepts second language and foreign language: definitional difficulties

Although there is both concept of a second language and a foreign language in the world, foreign researchers often combine these concepts using only one term - the second language, which contains a lot of information and can be used in different situations.

Foreign researchers emphasize that "it is wise to include the term foreign language in a more general term, the second language, because we (Mitchell, Myles, 2013, 5-6) believe that the learning process is the same for both closer and more distant languages, although there is a different purpose and circumstances of learning". This means that foreign researchers tend to combine these terms for convenience, although they emphasize that there are differences between them. This view is also expressed by Lydia White: "There will be no differences made between the acquisition of the second language and the acquisition of a foreign language. In principle, any acquisition or learning process of a non-native language will have the same constraints, although the limited use of the language in question could be the main obstacle in the context of learning a given foreign language (White, 2003, XII).

Although foreign literature emphasizes that the terms second language and foreign language have different functions, however, these concepts are often merged into one term - the second language. "The second language has social functions in the environment in which it is acquired, while the foreign 
language is acquired mainly in order to communicate with members of a particular community. I [William Littlewood] agree that this is a useful distinction. However, in this book [Foreign and Second Language Learning] the term second language is used as an encompassing term for both the second language and the foreign language" (Littlewood, 1998, 2).

Taking into account all the aforementioned features of the concept of the second language - any language other than the native language; language environment and the way in which the language is acquired, it can be concluded that, for the sake of convenience, foreign researchers use the term second language, it being understood as any language acquired after the native language, although not all languages share the same learning objectives, moreover, the environment in which the language is learned also varies. It has led the foreign researchers to believe that the term second language is not very successful for such use. Rod Ellis, for example, indicates that the second language refers certain learning environments such as South Africa, which is related to black language learners, and then the term second language can be interpreted as an insult (Ellis, 1997, 11). R. Ellis suggests using the term additional language as a more acceptable term for the term second language (Ellis, 1997, 11). The term additional language is also supported by some other foreign authors, stating that it can be used to exclude any sequence of the language acquired after the first language. In addition, researchers also acknowledge that the term additional language is more encompassing than the second language acquired in chronological order (Loewen, Reinders, 2011, XI).

Although the term additional language is much more successful, it has not gained popularity and studies continue to use the term second language.

M. Smith has also written about the term second language, and he emphasizes that the term second language is better than secondary or non-native language, which indicate a lower status (Smith, 2014, 7).

D. Larsen-Freeman and M.H. Long emphasize that in today's world the acquisition of second language is widespread. This does not concern only schools, as language acquisition affects many other aspects of people's lives. English as a second language for many people in the world is increasingly becoming an international language in fields of business and trade, science and technology, as well as international relations and diplomacy. Many industry professionals from different parts of the world meet in conferences, congresses and conversational language (working language) very often is English (LarsenFreeman, Long, 2014; Kramsch, 2008, 4).

D. Crystal emphasizes that English is now widely acquired also as a foreign language. In more than 100 countries such as China, Russia, Germany, Spain, Egypt and Brazil, as well as in many other countries, it is the main foreign language that children learn at school, often ousting other languages, for example, in 1996, English replaced the French language as the main foreign language in the schools of Algeria (former colony of France). D. Crystal also points out that English has already become a global language, since nearly a quarter of the world's population speaks English fluently or good enough, and this number is only rising. At the end of the $90 \mathrm{~s}$ of the 20th century, it ranged from 1.2 to 1.5 billion people. No other language can resemble this increase. Even the Chinese language, which has 8 spoken language forms but is unified by a common writing system, is known to only 1.1 billion people (Crystal, 2003, 3-5).

\section{Non-distinction of the concepts of a second language and foreign language}

Not all countries have a distinction between a second language and a foreign language, for example, in Poland only the term foreign language is used when referring to second language acquisition. (Grunhage-Monetti, Halewijn, Holland, 2003, 78).

There is a concept of foreign language in Estonia. The Estonian Language Act states that any language that is different from the Estonian language or Estonian sign language is considered a foreign language. The minority language in Estonia is also considered to be a foreign language historically used as their native language by Estonian citizens belonging to national minorities (Language Act, 2011).

In Lithuania two terms are used, namely, svetimoji kalba (lit. alien) and uzsienio kalba (lit. foreign). The non-native or "alien" language (svetimoji kalba) is the language that a person learns purposefully at school or in special courses. A significant difference between the native language and "alien" language is the following - native language is the first language that the person acquires in early childhood. The "alien" language is learned later than the second or third language. The "alien" language can also be 
perceived as a "foreign" language (uzsienio kalba), i.e. language of another country, such as English language and French language in Lithuania, and also as a national language, which is really not the native language for some of the citizens, for example, for Russians, Poles and other citizens living in Lithuania the Lithuanian language is not the native language, but for them it is not also a "foreign" language. This means that the concept of svetimoji kalba is wider than the concept of užsienio kalba (Negimtoji arba svetimoji..., 2018). A similar explanation can be found in Ineta Dabašinskiene's and Raminta Garuckaite’s article "Early Foreign Language Acquisition - Unanswered Questions” („Agrina svesvalodas apguve - neatbildeti jautajumi") (Dabasinskiene, Garuckaite, 2009, 295). It allows us to conclude that the term uzsienio kalba corresponds to the term foreign language used in the world, while the svetimoji kalba would be the language which is elsewhere in the world referred to as the second language.

In the "Multilingual Thesaurus of the European Union", alongside the English term foreign language and the Latvian term svesvaloda, Lithuanian term uzsienio kalba is used (EuroVoc, 2008).

\section{Conclusions}

With regard to the understanding of concept of a second language and foreign language, it should be emphasized that in the world, the term second language is used extensively, both in terms of the second language acquired chronologically and majority language, which is known by minorities, as well as any language other than the native language. By contrast, in Latvia, the term second language is understood mainly as the majority language, which the minorities should know. Foreign researchers sometimes choose the term second language as a convenient and encompassing term to designate both foreign language and second language in the sense understood by the Latvian researchers, even though also abroad these are two distinct concepts. Whereas in Latvia, the distinction between these concepts is more specific.

Although in Latvia the distinction of the concepts of second language and foreign language is more specific than in the world, the content of the concept LAT2 is slowly changing, which is revealed in the earlier studies of the author of the article.

\section{Bibliography}

1. Bliska I. (2015). Francu valoda ka tresa valoda Latvija: leksiski semantiskais macibu limenis (French language as third language in Latvia: lexical semantic educational level). Doctoral Thesis. Liepaja: Liepajas universitate. Retrieved from https://www.liepu.lv/uploads/files/PD_Inga_Bliska.pdf (in Latvian)

2. Cook G. (2003). Applied Linguistics. Oxford, UK: Oxford University Press.

3. Crystal D. (2003). English as a Global Language. ( $2^{\text {nd }}$ ed.). New York: Cambridge University Press. Retrieved from

http://culturaldiplomacy.org/academy/pdf/research/books/nation branding/English_As A Global Language - David Crystal.pdf

4. Dabasinskiene I., Garuckaite R. (2009). Ankstyvasis uzsienio kalbos mokymas - neatsakyti klausimai (Early foreign language training - unanswered questions). Kalbos Kultūra, 82, 294 - 307. (in Lithuanian)

5. De Bot K., Lowie W., Verspoor M. (2005). Second Language Acquisition: An Advanced Resourse Book. New York: Routledge.

6. Ellis R. (1997). Second Langugage Acquisition. California: Oxford University Press.

7. EuroVoc. (2008). Multilingual Thesaurus of the European Union. Retrieved from http://eurovoc.europa.eu/drupal/?q=lv/request\&view=pt\&termuri=http://eurovoc.europa.eu/26846 4\&language $=$ lv

8. Gass S.M., Selinker L. (2008). Second Language Acquisition. ( $3^{\text {rd }}$ ed.). New York and London: Routledge. Retrieved from https://blogs.umass.edu/moiry/files/2015/08/Gass.Second-LanguageAcquisition.pdf

9. Grunhage-Monetti M., Halewijn E., Holland C. (2003). ODYSSEUS: Second Language at the Workplace. Kapfenberg, Austria: Council of Europe Publishing. Retrieved from https://languageforwork.ecml.at/Portals/48/HtmlTagFiles/bd62bf85-2dc2-48da-9261$\underline{0 \mathrm{c} 562574402 \mathrm{~b} . \mathrm{pdf}}$ 
10. Johnson K., Johnson H. (Eds.). (1999). Encyclopedic Dictionary of Applied Linguistics. UK and USA: Blackwell Publishing. Retrieved from http://citeseerx.ist.psu.edu/viewdoc/download?doi=10.1.1.453.447\&rep=rep1\&type=pdf

11. Knapp K., Seidlhofer B. (Eds.), Widdowson H. (2011). Handbook of Foreign Language Communication and Learning. Berlin: Walter De Gruyter GmbH.

12. Kramsch C. (2008). Applied linguistic theory and second / foreign language education. Encyclopedia of Language and Education. Boston: Springer Science and Business Media LLC.

13. Language Act. (2011). Tallinn: Riigi Teataja. Retrieved from https://www.riigiteataja.ee/en/eli/ee/515012014002/consolide/current

14. Larsen-Freeman D., Long M.H. (2014). An Introduction to Second Language Acquisition Research. $\left(1^{\text {st }}\right.$ ed.). New York: Routledge.

15. Littlewood W. (1998). Foreign and Second Language Learning. UK: Cambridge University Press.

16. Loewen S., Reinders H. (2011). Key concepts in second language acquisition. UK: Palgrave.

17. Mitchell R., Myles F. (2013) Second Language Learning Theories. London: Routlege.

18. Negimtoji arba svetimoji kalba (Unclear or alien language). (2018). Kalbos Lietuvos miestuose. Sociolingvistinis zemelapis. Retrieved from http://www.kalbuzemelapis.flf.vu.lt/lt/zinynas/negimtoji-arba-svetimoji-kalba-/ (in Lithuanian)

19. Robinson P. (Ed.). (2013). The Routledge Encyclopedia of Second Language Acquisition. London and New York: Routledge.

20. Smith M.S. (2014). Second Language Learning: Theoretical foundations. New York: Routledge.

21. White L. (2003). Second Language Acquisition and Universal Grammar. USA: Cambridge University Press. Retrieved from

https://eclass.uoa.gr/modules/document/file.php/GS345/White\%20\%282003\%29.\%20Second\%2 OLanguage\%20Acquisition\%20and\%20Universal\%20Grammar.pdf 